\title{
Publication of a Special Issue: Eicosanoid Receptors and Their Role in Regulating Immune and Inflammatory Responses
}

\author{
Claire Redhead \\ TheScientificWorld \\ E-mail: credhead@thescientificworld.com
}

Published August 9, 2007

TheScientificWorldJOURNAL is pleased to have published the special issue 'Eicosanoid Receptors and Their Role in Regulating Immune and Inflammatory Responses', a collection of peer-reviewed papers on a range of key topics in this field. The issue has been organized by Dr. Charles Brink, (CNRS CR-1, Paris, France) with the assistance of Dr. Xavier Norel. Specific topics covered are:

Activation and Regulation of Cellular Eicosanoid Biosynthesis.

Thomas G. Brock and Marc Peters-Golden

Structural Manipulation of Eicosanoid Receptors and Cellular Signaling.

Charles Brink

Regulation of Immune Cells by Eicosanoid Receptors.

Nancy D. Kim and Andrew D. Luster

Prostaglandin Receptor Signaling in Disease.

Toshiyuki Matsuoka and Shuh Narumiya

Cytokine-Leukotriene Receptor Interactions.

Marek Rola-Pleszczynski and Jana Stankova

Prostanoid Receptors in the Human Vascular Wall.

Xavier Norel

Cysteinyl-Leukotriene Receptors and Cellular Signals.

G. Enrico Rovati and Valerie Capra

Lipoxin Receptors.

Mario Romano, Irene Recchia and Antonio Recchiuti

The Role of Leukotriene Receptor Signaling in Inflammation and Cancer.

Ramin Massoumi and Anita Sjölander 
Leukotriene Receptors: Crucial Components in Vascular Inflammation.

Magnus Bäck

Endogenous Receptor Agonists: Resolving Inflammation.

Gerard Bannenberg, Makoto Arita and Charles N. Serhan

The Publisher wishes to thank the authors and reviewers, and especially acknowledges the contribution of Dr. Brink in bringing about the publication of this special issue.

This article should be cited as follows:

Redhead, C. (2007). Publication of a Special Issue: Eicosanoid receptors and their role in regulating immune and inflammatory responses. TheScientificWorldJOURNAL 7, 1149-1150. DOI 10.1100/tsw.2007.225. 

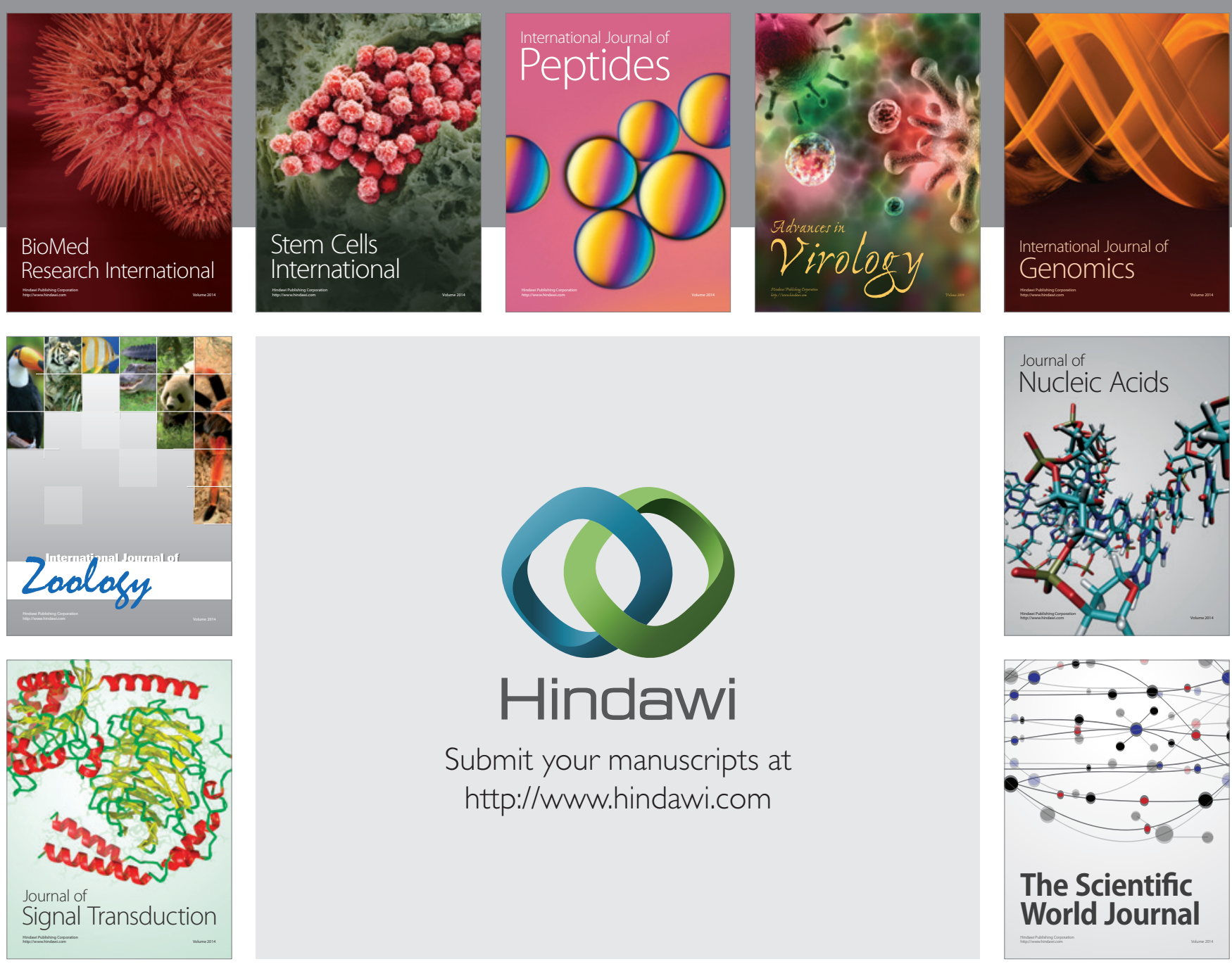

Submit your manuscripts at

http://www.hindawi.com
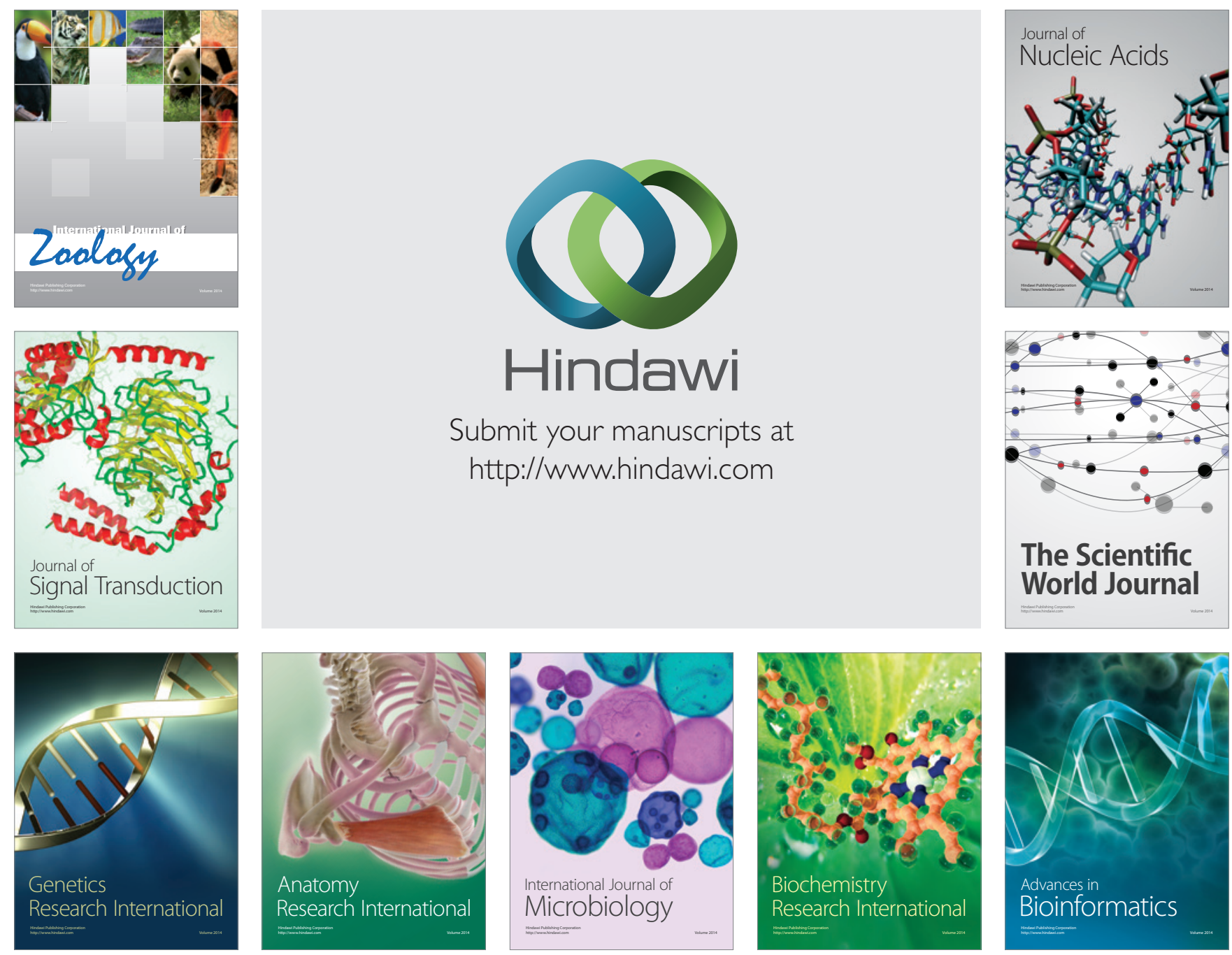

The Scientific World Journal
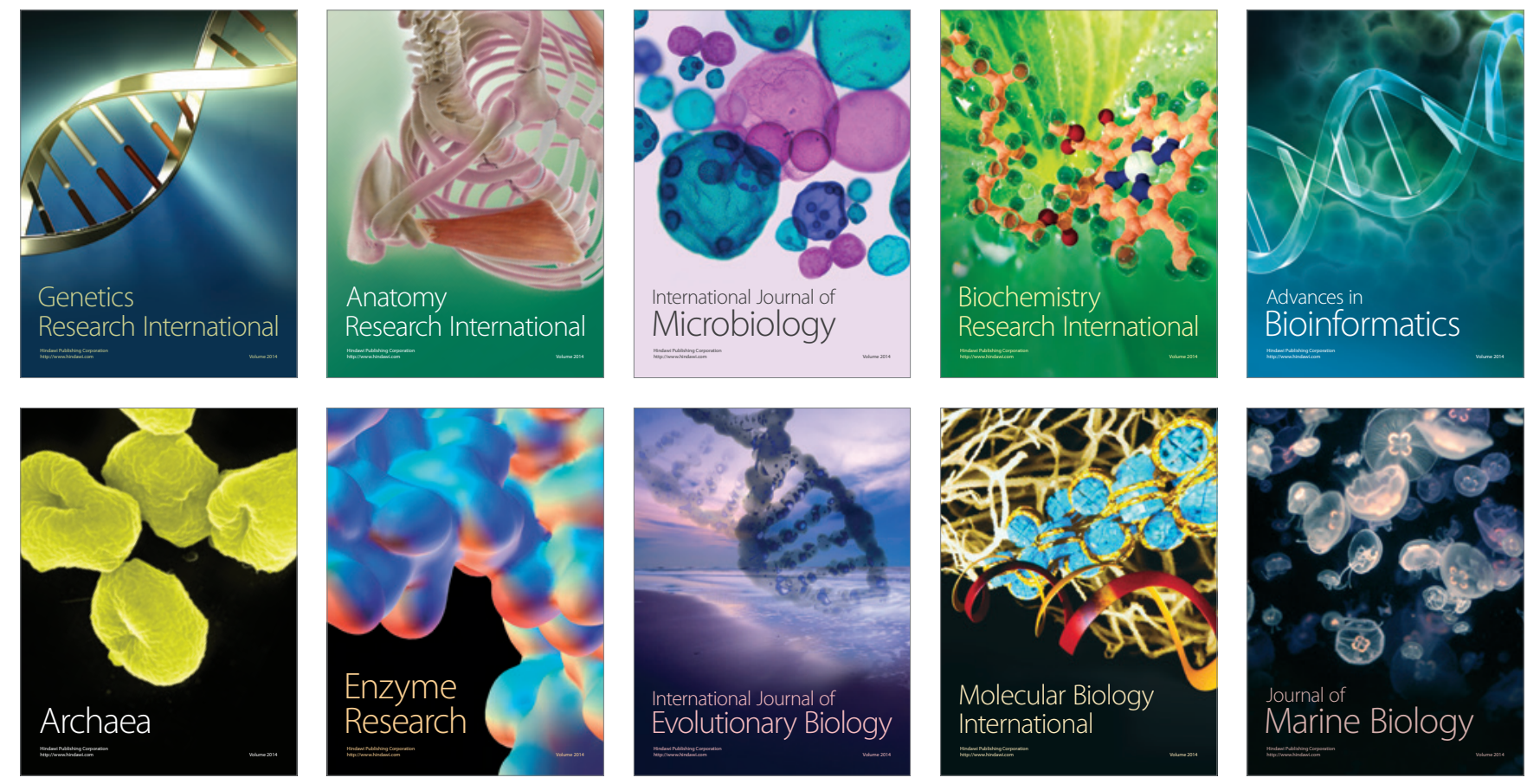